Supplementary material for

\title{
Antitumor potential of cisplatin loaded into SBA-15 mesoporous silica nanoparticles against B16F1 melanoma cells: in vitro and in vivo studies
}

By the authors:

Dijana Drača, David Edeler, Mohamad Saoud, Biljana Dojčinović, Duško Dunđerović, Goran Đmura, Danijela Maksimović-Ivanić, Sanja Mijatović and Goran N. Kaluđerović

Table S1. Clinical parameters of disease

\begin{tabular}{|c|c|c|c|c|c|c|c|}
\hline Group & $\begin{array}{c}\text { body } \\
\text { weight } \\
\text { lost (10- } \\
\mathbf{1 5 \% )}\end{array}$ & piloerection & $\begin{array}{c}\text { vocalization } \\
\mathbf{s}\end{array}$ & $\begin{array}{c}\text { heavy } \\
\text { breathing }\end{array}$ & $\begin{array}{c}\text { aggravated } \\
\text { moving }\end{array}$ & hunching & $\begin{array}{c}\text { unusual } \\
\text { interactions }\end{array}$ \\
\hline control & $0 / 7$ & $0 / 7$ & $2 / 7$ & $0 / 7$ & $1 / 7$ & $0 / 7$ & $0 / 7$ \\
\hline$C P$ & $7 / 7$ & $7 / 7$ & $7 / 7$ & $7 / 7$ & $7 / 7$ & $7 / 7$ & $7 / 7$ \\
\hline$S B A-15 \mid C P$ & $0 / 7$ & $0 / 7$ & $0 / 7$ & $0 / 7$ & $0 / 7$ & $0 / 7$ & $0 / 7$ \\
\hline
\end{tabular}

